\title{
THE EFFECTIVENESS OF PROBLEM-BASED LEARNING APPROACH IN THE TEACHING OF HANG STYLE LONG JUMP
}

\author{
Octavianus Cahyanto Adhie \\ Correspondence: SMKN 1 Cangkringan, Sleman, Special Region of Yogyakarta \\ E-mail: ocahyantoadhie@gmail.com
}

\begin{abstract}
The learning improvement of physical education can be done through implementing learning approach which is suitable for 21st Century era. This research is a descriptive quantitative research which aims to describe the effectiveness of the hang style long jump learning using problem-based learning approach based on students' learning outcomes and attitude in vocational high school context. The subject of the research were students of $X$ ATR 1 and $X$ TKRO 1 students of SMKN 1 Cangkringan. The data were obtained from the result of observation sheets, learning outcome tests, and questionnaire of students' attitudes towards learning. The result showed that hang style long jump learning using problem-based learning approach was effective based on students' learning outcomes and learning attitudes. The passing students reached $100 \%$ for $X$ ATR 1 students and 80,65\% for X TKRO 1 students. The students' learning attitudes towards physical education subject in the category of minimum more than $80 \%$ high were $100 \%$ for X ATR 1 students and $90.32 \%$ for X TKRO 1 students.
\end{abstract}

Keywords: Effectiveness, Hang Style Long Jump Learning, Problem-Based Learning Approach

\section{Introduction}

Education is one way to prepare students to face problems that become increasingly complex. The $21^{\text {st }}$ century education puts forward the following abilities: thinking critically and making judgments; solving complex, multidisciplinary, open ended problems; creativity and entrepreneurial thinking; communicating and collaborating; making innovative use of knowledge, information, and opportunities; and taking charge of financial, health, and civic responsibility (Winataputra, 2013). Those abilities implies that education, as well as Physical education not only plays role as knowledge source, but also as shaping mindset and students' attitudes.

Physical education is a learning process through physical activities designed to improve physical fitness, develop motor skills, knowledge and healthy and active behaviors, sportsmanship, and emotional intelligence as stated by Samsudin (2008). Physical education itself is a subject that has a vital position in the development of human resources. The existence of physical education is recognized by the government stated in Republik Indonesia Law No. 20 year 2003

PJKR

https://jurnal.unimed.ac.id/2012/index.php/jpehr 
article 42, which explains the content of the primary and secondary education curriculum, which defines Physical education lessons as subjects that must be given in schools from elementary to high school levels.

In order to educate and develop students' skills, physical education trains students on how to behave and set a mindset in dealing with various problems in everyday life. One of the ways to do this is reflected through an appropriate learning approach.

There are many problems in the teaching and learning of physical education, one of which is most shools still apply conventional and teacher-centered learning so that students are less involved in the learning process. This can make students' thinking skills are not trained. In addition, the lack involvement of students in physical education learning results in less meaningfulness of physical education for students which can gradually reduce students' interest in the learning process. Students' disinterest will reduce attitudes towards physical education learning in a long time.

Attitude is a mental and nervous state of readiness, which is organized through experience, exerting instructions or dynamic influence on individual responses to all objects and situations related to students, which will be able to ensure the continuity of learning activities and provide direction to learning activities, so that the desired goals of students can be achieved.

In relation to learning outcomes, students' attitudes are very important for students. To achieve competence and good learning outcomes, students need to have positive attitudes towards physical education. Students who like physical education will increase their intrinsic motivation to learn and vice versa. Therefore, during the learning process, it is necessary to pay attention to many factors, including the materials and the characteristics of the physical education itself, teaching practices, field activities, and physical education teachers as facilitators in the learning process. ation. Health and Recreation

One of the physical education learning materials discussed at vocational high school is long jump. Long jump is a movement to jump to the peak which is done fast and fits to the repulsion path on one leg to reach the jump as far as possible (Muslimin \& Ramadhan, 2017). The basic principle of the long jump is to achieve the highest starting speed while still being able to make a strong upward repulsion with one foot to achieve sufficient hover height for the best possible jump distance. The long jump itself has four stages, namely prefix, repulsion, hovering, and landing (Kamnardsiri et al, 2015; Coh et al 2017). Therefore, a good jumper needs to have good physical and technical conditions.

To overcome this, the teacher as a facilitator in physical education learning needs to think about a learning approach that prevents teacher-centered learning. This learning approach can improve students' understanding on physical education in long jump, as well as give chance for them to think freely. Therefore, the students can develop their thinking skills and learning attitudes towards Physical education.

PJKR

https://jurnal.unimed.ac.id/2012/index.php/jpehr 
Scientific approach is an alternative in learning that pays attention to students' thinking skills including critical thinking skills. The are many models of learning in scientific approach, one of which is problem-based learning. Problembased learning is designed to help students develop their thinking skills, problemsolving skills, and intellectual skills; learn adult roles by experiencing them through real or simulated situations; and become independent and autonomous learners (Arends, 2013).

Problem-based learning approach features collaboration which allows students to team up with one another. Cooperation among students will give motivation for further involvement in complex tasks (Arends, 2013). Furthermore, Tan (2009) explains "problem based learning optimizes on goals, needs and the motivation that drives learning." The existence of cooperation and involvement among students will encourage students to have interest in learning.

The implementation of problem-based learning is expected to optimize the attitudes of students towards learning because attitudes are characteristics of someone who describes their positive and negative feelings towards a particular object, situation, institution, person or idea, goals, needs, and motivation that drive learning (Nitko, 2011). With these considerations, a study is conducted which aims to describe the effectiveness of the problem-based learning approach in terms of learning outcomes and attitudes towards learning in vocational high schools in hang style long jump learning.

\section{Method}

The research method of the study is quantitative descriptive as it describes things sistematically and accurately (Sugiyono, 2012). The intended abilities are the learning outcomes and students' attitudes towards hang style long jump learning after implementing problem-based learning approach.

This research was conducted at SMK N 1 Cangkringan, Sleman. The research subjects were class $X$ students majoring in ATR 1 and TKRO 1 in the academic year of 2019/2020. The data collection instruments used were a learning outcome test and an attitude questionnaire towards physical education learning. The test questions consisted of ten multiple choices and three essays. Furthermore, the attitude questionnaire towards physical education learning consisted of 30 statement items measuring the cognitive, affective, and active dimensions. In addition to the two instruments, the learning implementation observation sheet instrument was also used to ensure that the problem-based learning approach could be applied with a minimum category well during each meeting in the two subject classes.

The learning outcome test was analyzed by determining the percentage of minimum score achievement. The attitude questionnaire towards physical education learning was analyzed descriptively by determining the total score of each student. Then, the scores were converted into 5 categories, namely Very High, High, Fair, Low, and Very Low.

PJKR_

https://jurnal.unimed.ac.id/2012/index.php/jpehr 
The effectiveness of physical education learning material hang style long jump using a problem-based learning approach was seen from the following two points. 1) Minimum $75 \%$ of the students reached the minimum completeness criteria for the basic competency test scores, and 2) minimum $80 \%$ of the students reached the high minimum category for attitudes (Kemp, 1994: 289).

\section{Result and Discussion}

Before answering the research questions, firstly, the results of learning implementation using problem-based learning approach which was carried out in two meetings were analyzed. The following table shows the results of the hang style long jump learning implementation using problem-based learning approach.

Table 1. Problem Based Learning Implementation

\begin{tabular}{ccccc}
\hline \multirow{2}{*}{ Meetings } & \multicolumn{2}{c}{ X ATR 1 } & \multicolumn{2}{c}{ X TKRO 1 } \\
\cline { 2 - 5 } & \% & Category & \% & Category \\
\hline 1 & 93,33 & Very good & 80 & Good \\
\hline 2 & 93,33 & Very good & 73,33 & Good \\
\hline
\end{tabular}

Table 1 shows that the percentage of learning implementation both in class X ATR 1 and X TKRO 1 fulfills the minimum "Good" category. Furthermore, the implementation of project based learning in class X ATR 1 are in the very good category. Thus, the PBL approach can certainly be applied in the hang style long jump learning.

The effectiveness of the data were obtained from the result of learning outcome test and attitude questionnaires towards physical education learning. The data were collected 1 (one) time, at the $3^{\text {rd }}$ meeting after the hang style long jump learning was applied using learning materials with problem-based learning approach.

The collection of effectiveness data in class X ATR 1 were carried out on December $4^{\text {th }}, 2019$. On the other hand, in class X TKRO 1 , it was held on December $6^{\text {th }}, 2019$. Students in each class were determined to achieve the basic competency score. From the scores, the number of students who passed or did not pass were calculated and then the percentage of students' passing score of each class were deterined.

The following table shows the percentage recapitulation of students who passed the basic competency achievement test in the trial class, in X ATR 1 and X TKRO 1 of SMK N 1 Cangkringan.

Table 2. Passing Test Result

\begin{tabular}{ccccc}
\hline & \multicolumn{2}{c}{ X ATR 1 } & \multicolumn{2}{c}{ X TKRO 1 } \\
\cline { 2 - 5 } & $\begin{array}{c}\text { Number of } \\
\text { Students }\end{array}$ & $\boldsymbol{\%}(\mathbf{N}=\mathbf{3 2})$ & $\begin{array}{c}\text { Number of } \\
\text { Students }\end{array}$ & $\begin{array}{c}\text { \% } \\
(\mathbf{N}=\mathbf{3 1})\end{array}$ \\
\hline Passed & 32 & $100 \%$ & 25 & $80,65 \%$ \\
\hline Not passed & 0 & $0 \%$ & 6 & $19,35 \%$ \\
\hline
\end{tabular}

PJKR_

https://jurnal.unimed.ac.id/2012/index.php/jpehr 
Based on the above table, the percentage of students who passed the KKM in class X ATR 1 and class X TKRO 1 meets the minimum criteria of $75 \%$. With these results and based on the test effectiveness criteria as previously mentioned, it can be concluded that the hang style long jump learning using problem-based learning approach was effective in terms of students' learning outcomes.

Meanwhile, from the results of the attitude questionnaire towards physical education, the recapitulation results were obtained as follows.

Table 3. The Percentage of Students' Ability Questionnaire towards Physical Education

\begin{tabular}{ccccc}
\hline Category & \multicolumn{2}{c}{$\begin{array}{c}\text { X ATR 1 } \\
(\mathbf{N = 3 2})\end{array}$} & \multicolumn{2}{c}{$\begin{array}{c}\text { X TKRO 1 } \\
(\mathbf{N}=\mathbf{3 1})\end{array}$} \\
\cline { 2 - 5 } & $\begin{array}{c}\text { Number of } \\
\text { Students }\end{array}$ & $\begin{array}{c}\text { Number of } \\
\text { Students }\end{array}$ & \% \\
\hline Very high & 13 & $40,425 \%$ & 15 & $48,387 \%$ \\
\hline High & 19 & $39,375 \%$ & 13 & $41,935 \%$ \\
\hline Fair & 0 & $0 \%$ & 1 & $3,226 \%$ \\
\hline Low & 0 & $0 \%$ & 2 & $0,452 \%$ \\
\hline Very Low & 0 & $0 \%$ & 0 & $0 \%$ \\
\hline
\end{tabular}

Based on the results of the attitude questionnaire, the percentage of students of X ATR 1 who falls into minimum high category were $100 \%$. On the other hand, in X TKRO 1, the percentage of students who meet the minimum high category were $90.322 \%$. These results indicates that the hang style long jump learning using problem-based learning approach was effective as seen on the results of the students' questionnaire on physical education.

The effectiveness results in terms of learning outcomes support the results of a research conducted by Jojo (2019). In his study, it was found that problem-based learning method could improve the psychomotor processes of students, because students immediately knew the problem points so that students focused on solving problems and therefore, it could improve the learning outcomes of Immanuel Vocational School on Students' Long Jump.

The results of the effectiveness in terms of attitudes towards physical education learning above are in accordance with the research conducted by Stanilaus Amsikan (2010) that problem-based learning is effective in improving the thinking skills of students' attitudes.

\section{Conclusion}

Based on the results and discussions, it can be concluded that the hang style long jump learning with project based approach was effective in terms of learning outcomes and attitudes towards learning. The passing rate of the learning outcomes test reaches $100 \%$ for X ATR 1 and $80.65 \%$ for X TKRO 1. The attitudes of students towards Physical education falls into minimum high category of more than $80 \%, 100 \%$ for X ATR 1 and $90,32 \%$ for X TKRO 1.

PJKR_

https://jurnal.unimed.ac.id/2012/index.php/jpehr 


\section{References}

Amsikan, S.(2010). Keefektifan pembelajaran matematika dengan model problem based learning dan model cooperative learning type jigsaw di SMP. (Tesis magister, tidak diterbitkan, Universitas Negeri Yogyakarta, Yogyakarta)

Arends, R.I. (2013). Learning to teach:belajar untuk mengajar ( $9^{\text {th }}$ ed). (Terjemahan Helly Prajitno Soetjipto dan Sri Mulyantini Soetjipto). New York:McGraw Hill Companies Inc.

Coh, M et al. (2017). Kinematic and Biodynamic Model of the Long Jump Technique. http://dx.doi.org/10.5772/interchopen.71418

Jojo, I. (2019). Pengaruh Metode Pembelajaran Problem Based Learning Terhadap Hasil Belajar Lompat Jauh Siswa SMK Imanuel 2. Jurnal Pendidikan dan Pembelajaran. Vol 8, No 3 (2019).

Kamnardsiri, T et al. (2015). Knowledge-Based System Framework for Training Long Jump Athletes Using Action Recognition.Journal of Advances in Information Technology Vol.6, No.4, November 2015. doi:10.12720/jait.6.4.182-193.

Kemp, J.E, Morris on G.R, \& M.Ross. (1994). Design effective instruction. New York: Macmillan College Publishing Company.

Muslimin \& Ramadhan, H.P. (2017). Cooperative learning jigsaw and student achievement division teams results of hang style long jump. International Journal of Pysical Education, Sports and Health (ijpesh), 4(3):191-196.

Nitko, A \& Bookhart, S. (2011). Educational assessment of students. ( $6^{\text {th }}$ ed). United States or America: Pearson Education, Inc.

Samsudin. (2008). Pembelajaran Pendidikan Jasmani Olahraga dan Kesehatan SMP/MTs. Penerbit: Litera. Jakarta.

Sugiyono.(2012). Metode Penelitian Kuantitatif, Kualitatif dan R\&D. Bandung: Alfabeta.

Tan, O.S et al. (2009) Problem-based Learning and Creativity Singapore: Cengage Learning.

Winataputra, U.S. (2013). Menyongsong dan memantapkan implementasi kurikulum 2 013: kebutuhan inovasi dalam pembelajaran. Makalah disajikan dalam Seminar Menyongsong Implementasi Kurikulum 2013, di Universitas Negeri Yogyakarta.

PJKR_

https://jurnal.unimed.ac.id/2012/index.php/jpehr 